\title{
REPRODUCTIVE ECOLOGY AND BEHAVIOR OF THOROPA MILIARIS (SPIX, 1824) (ANURA, LEPTODACTYLIDAE, TELMATOBIINAE)
}

\author{
Ariovaldo Antonio Giaretta \& Kátia Gomes Facure
}

Biota Neotropica v4 (n2) - http://www.biotaneotropica.org.br/v4n2/pt/abstract?article+BN03704022004

\author{
Date Received 06/09/2004 \\ Revised 09/17/2004 \\ Accepted 09/30/2003
}

\begin{abstract}
Laboratório de Ecologia e Sistemática de Anuros Neotropicais, Instituto de Biologia, Universidade Federal de Uberlândia, 38400-902, Uberlândia, Minas Gerais, Brasil, e-mail: thoropa@inbio.ufu.br
\end{abstract}

\begin{abstract}
Thoropa species are distributed in southern and southeastern Brazil and have semiterrestrial tadpoles on rocky environments. Herein, we provide further data on reproduction, paternal care and tadpole cannibalism in T. miliaris. Guarding males were tested for disturbances in their egg masses. Egg masses were laid in stripes of wet rock; eggs were in a single layer and were adhered to the rock surface, roots, and to one another. The tadpoles hatched between four and six days. The egg number in two egg masses was 750 and 1190; eggs were gray and the yolk were about $1.7 \mathrm{~mm}$ in diameter; $2.3 \mathrm{~mm}$ with the jelly capsule. Aggressive interactions were observed between males. Males remained with their egg masses during the night and reacted aggressively to the experimental disturbances. Late stage tadpoles were found cannibalizing eggs. An egg mass in a recently formed wet stripe died from drought. The strips of wet rock are the only places where eggs and tadpoles can develop and represent a limiting factor for reproduction because they occur in short supply. For the females, the selection of newly formed wet strips may represent a trade-off between the advantages of using places free of cannibalistic and/or competitive tadpoles and the risks of losing offspring by drought. Our results do not support Cycloramphinae as a valid taxon, indicating that the morphological and behavioral similarities between Thoropa and Cycloramphus species should be interpreted as convergence.
\end{abstract}

Key words: Thoropa miliaris, parental care, reproduction, cannibalism, Atlantic forest, Brazil.

\begin{abstract}
Resumo
Ecologia e Comportamento Reprodutivo de Thoropa miliaris (Spix, 1824) (Anura, Leptodactylidae, Telmatobiinae). As espécies de Thoropa estão distribuídas no sul e sudeste do Brasil e têm girinos semiterrestres em ambientes rochosos. Aqui apresentamos dados complementares sobre reprodução, cuidado paternal e canibalismo por girinos em T. miliaris. Machos guardiões foram testados quanto a perturbações às suas desovas. As desovas foram postas em faixas de umidade na rocha; os ovos foram postos em camada única e estavam aderidos à superfície da rocha, raízes e uns aos outros. Os girinos eclodiram entre quatro e seis dias após a oviposição. O número de ovos em duas desovas foi 750 e 1190 ; os ovos eram cinza e a porção vitelínica mediu cerca de 1,7 mm em diâmetro; 2,3 mm com a cápsula gelatinosa. Foram observadas interações agressivas entre os machos. Os machos permaneceram com suas desovas durante a noite e reagiram agressivamente às perturbações experimentais. Girinos em estágios tardios foram vistos canibalizando ovos. Uma desova em uma faixa de umidade recém formada morreu por desidratação. As faixas de umidade na rocha são os únicos locais onde os ovos e os girinos podem se desenvolver e representam um fator limitante para a reprodução porque são raras. Para as fêmeas, a seleção de faixas úmidas recém formadas deve representar um balanço entre as vantagens em ocupar lugares livres de girinos canibais e/ou competidores e os riscos de perda de prole por desidratação. Nossos resultados não apóiam Cycloramphinae como um táxon válido, indicando que as similaridades morfológicas e comportamentais entre as espécies de Thoropa e Cycloramphus devem ser interpretadas como convergência.
\end{abstract}

Palavras-chave: Thoropa miliaris, cuidado parental, reprodução, canibalismo, Mata Atlântica, Brasil. 


\section{Introduction}

The five species of the genus Thoropa Cope, 1865 are distributed in southern and southeastern Brazil (Frost 2004); four species occur in forest environments (Bokermann 1965, Cocroft \& Heyer 1988) and one occurs in altitudinal fields (Caramaschi \& Sazima 1984). All species are known to live on rocky environments and have semiterrestrial tadpoles, which inhabit shallow slow flowing water on surfaces of rocks (Wandolleck 1907, Lutz 1947, Heyer \& Crombie 1979, Caramaschi \& Sazima 1984, Cocroft \& Heyer 1988, Heyer et al. 1990). Brief accounts on habitat and egg clutches were provided by Wandolleck (1907), Bokermann (1965), Lutz (1974), Heyer \& Crombie (1979), and Caramaschi \& Sazima (1984).

Among the species of the genus, T. miliaris (adults 54 - 71 mm SVL, Heyer et al. 1990) has the widest distribution (Cocroft \& Heyer 1988) and is found in rocky environments near the coast in southeastern Brazil. Herein we provide data on egg clutches, time up to hatching, mortality sources of eggs, cannibalism of tadpoles upon eggs, and territoriality. We also present evidences of paternal care in T. miliaris. We regard the similarities in the ecology and behavior of Thoropa and some Cycloramphus Tschudi 1838 (Gripiscini) species as convergence and argued against the acceptance of Cycloramphinae (Frost 2004) as a valid taxon.

\section{Material and Methods}

Field work was carried out at Praia da Enseada, mu-

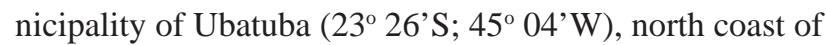
the State of São Paulo. In the region, the original vegetation is Atlantic Rain Forest, which is still abundant. The local climate is wet tropical and annual rainfall is around 2,600 $\mathrm{mm}$, with January having the greatest average rainfall. Mean annual temperatures are around $22^{\circ} \mathrm{C}$ (Morellato et al. 2000).

Observations were made daily between 22 December 2002 and 5 January 2003, 5-9 March 2003, and 9-10 April 2004. A study plot was established where four males were found calling. The reproductive aggregate was in an $18 \mathrm{~m}$ long ledge of granite rock, close $(5 \mathrm{~m})$ to the sea, but out of reach of the high tide, waves or splashes. This granite ledge was sloped $\left(40-50^{\circ}\right)$ toward the sea and had the upper border covered by ornamental (cultivated) $2 \mathrm{~m}$ high plants. Within the plot there were three short (2-3 m) and narrow (0.3 - $0.6 \mathrm{~m}$ wide) strips of rock covered by a film of fresh water. Two of these strips retained water all through the December-January study period, during this period one of them dried out after 2-3 days without rain.

Males were individualized by their size and their yellow back mottling pattern. Tadpoles and egg masses were searched for in all the wet surfaces. When two males were found close $(0-10 \mathrm{~cm})$ to the same egg mass we presumed that the largest and most aggressive one was the father. Embryos and tadpoles were staged following Gosner (1960).
As the eggs were firmly adhered to the rock surface and were difficult to remove, egg number was estimated from close-up photographs of individual egg masses. Hatching time was based on egg masses of known age. To determine the daily pattern of activity of the tadpoles on areas directly exposed to the sunlight, we counted their number on a 0.25 $\mathrm{m}^{2}$ plot at a wet strip (site 1 , see below) during the day and the night.

In the December-January study period, four resident males were tested for their reaction to disturbance of their egg masses or surrounding ground (males without egg masses). To perform this, we experimentally touched their egg masses or the ground in their vicinities $(10 \mathrm{~cm})$ for $3 \mathrm{~min}$ with the tip (10 mm diameter ring) of a fine $1.5 \mathrm{~m}$ long stick. Each male was tested 2-3 times during the study period, just once within a $24 \mathrm{~h}$ period. We conducted all the tests after sun down, when the males were found at their sites. Before each experimental procedure, each male was illuminated for 2 min to allow accommodation.

For comparative purposes (see discussion), the egg number and egg size of Thoropa miliaris, T. megatympanum Caramaschi \& Sazima 1984 and Cycloramphus boraceiensis Heyer 1983 were determined based on museum specimens. Females bearing mature eggs (hypertrophied and convolute oviducts) were dissected and their eggs isolated from each other for counting and measurements.

\section{Results}

December-January period - Calling and spawning activities were limited to 1-2 nights after rainy days. Three egg masses were found in the wet strips, in places covered and shaded by leaves, but close $(<30 \mathrm{~cm})$ to the rock surface exposed to the sun (Fig. 1). Eggs were laid in a single layer and firmly adhered to the rock surface and frequently to one another and were spread over the rock in irregular areas (within about $250 \mathrm{~mm}$ in diameter) (Figs. 2 and 3). The tadpoles of one egg mass hatched between four and six days. One of these egg masses hatched 3.5 days after being laid and the other died from drought before hatching. The egg number in two egg masses was estimated as 750 and 1190.

In the study plot, males were seen at the wet strips only during the night. The males were associated with egg masses, remaining on or close to $(<15 \mathrm{~cm})$ them (Fig. 4) during the night. Two males of very different sizes lived close $(<30 \mathrm{~cm})$ together (hereafter called site 1$)$. The other two males were solitary and were ca. of 4 (site 2) and $15.3 \mathrm{~m}$ (site 3 ) from the site 1 and ca. $11 \mathrm{~m}$ from each other. Aggressive interaction was observed once between the two males of site 1 , with the large one expelling the smaller from his vicinity $(5 \mathrm{~cm})$ by hitting him with his head and by calling aggressively (in a faster rate than that of the advertisement call); the smaller reacted by fleeing to a greater distance (ca. 


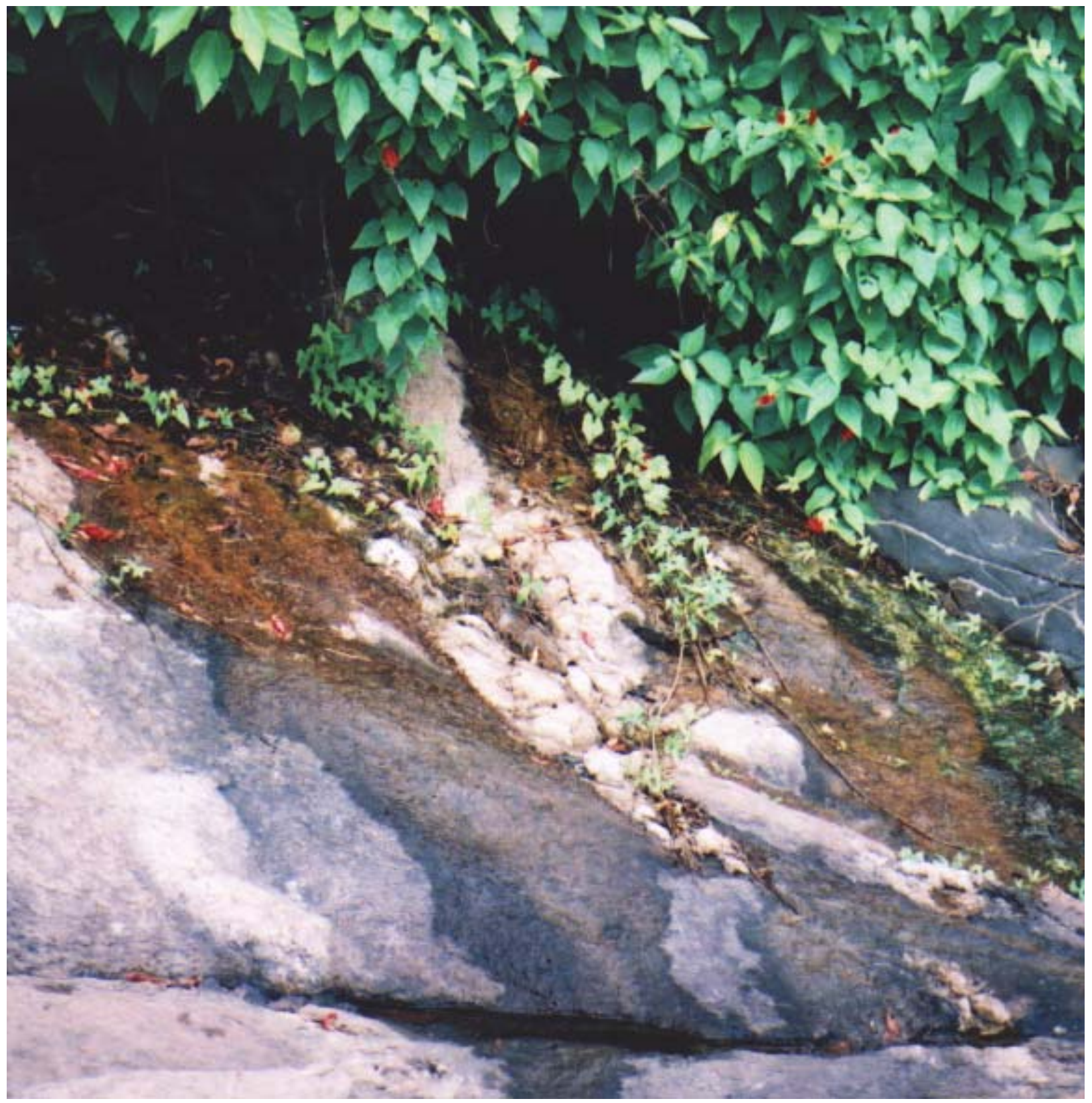

Figure 1- Habitat of reproduction of Thoropa miliaris, note the wet stripes (darker rock surface) formed by a film of water that flows from beneath the plants. Municipality of Ubatuba, São Paulo, Brazil. 


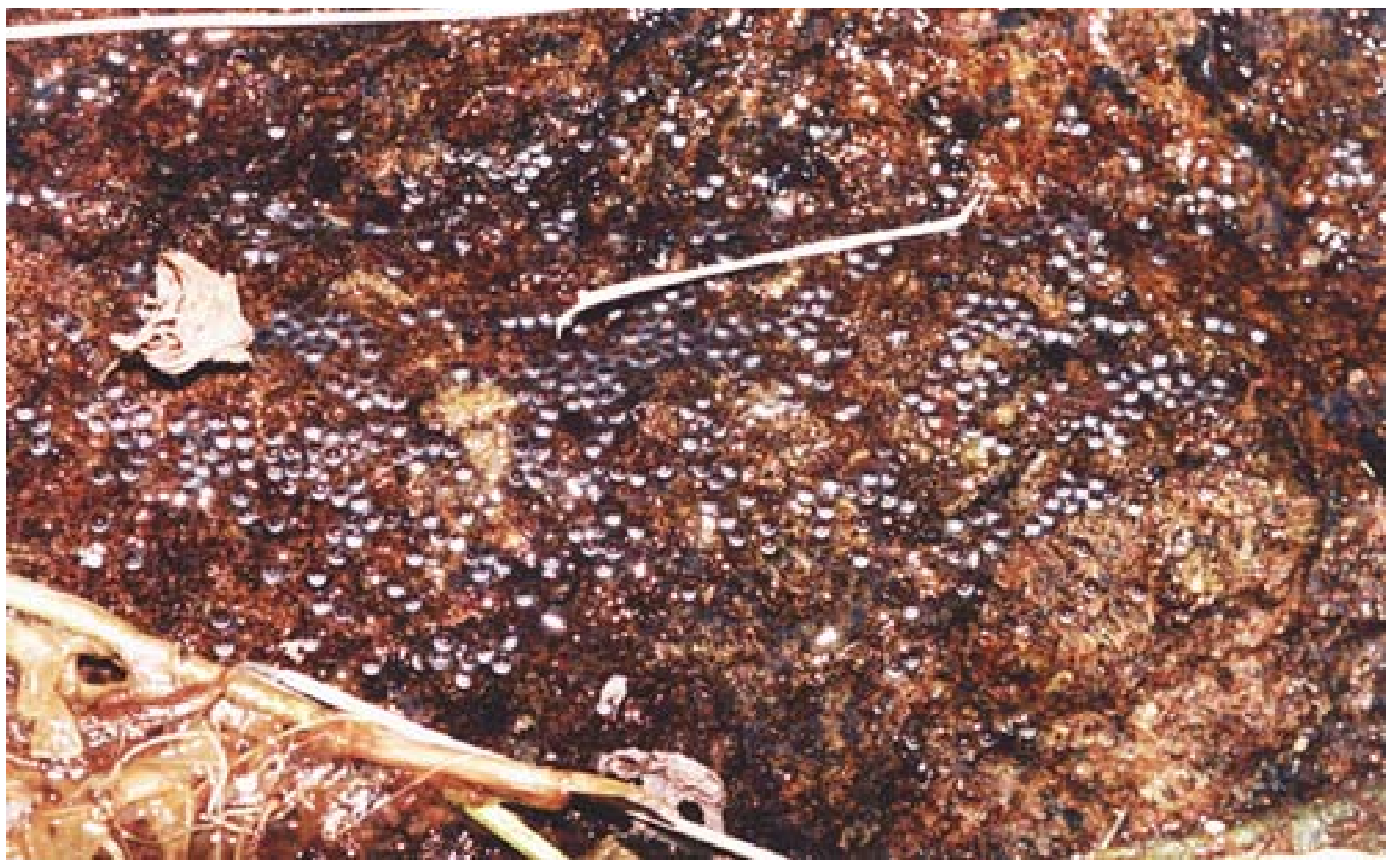

Figure 2- Detail of a portion of an egg mass of Thoropa miliaris, note that the eggs are in a single layer, adhered to the rock and either in contact with each other or isolated. Municipality of Ubatuba, São Paulo, Brazil. 


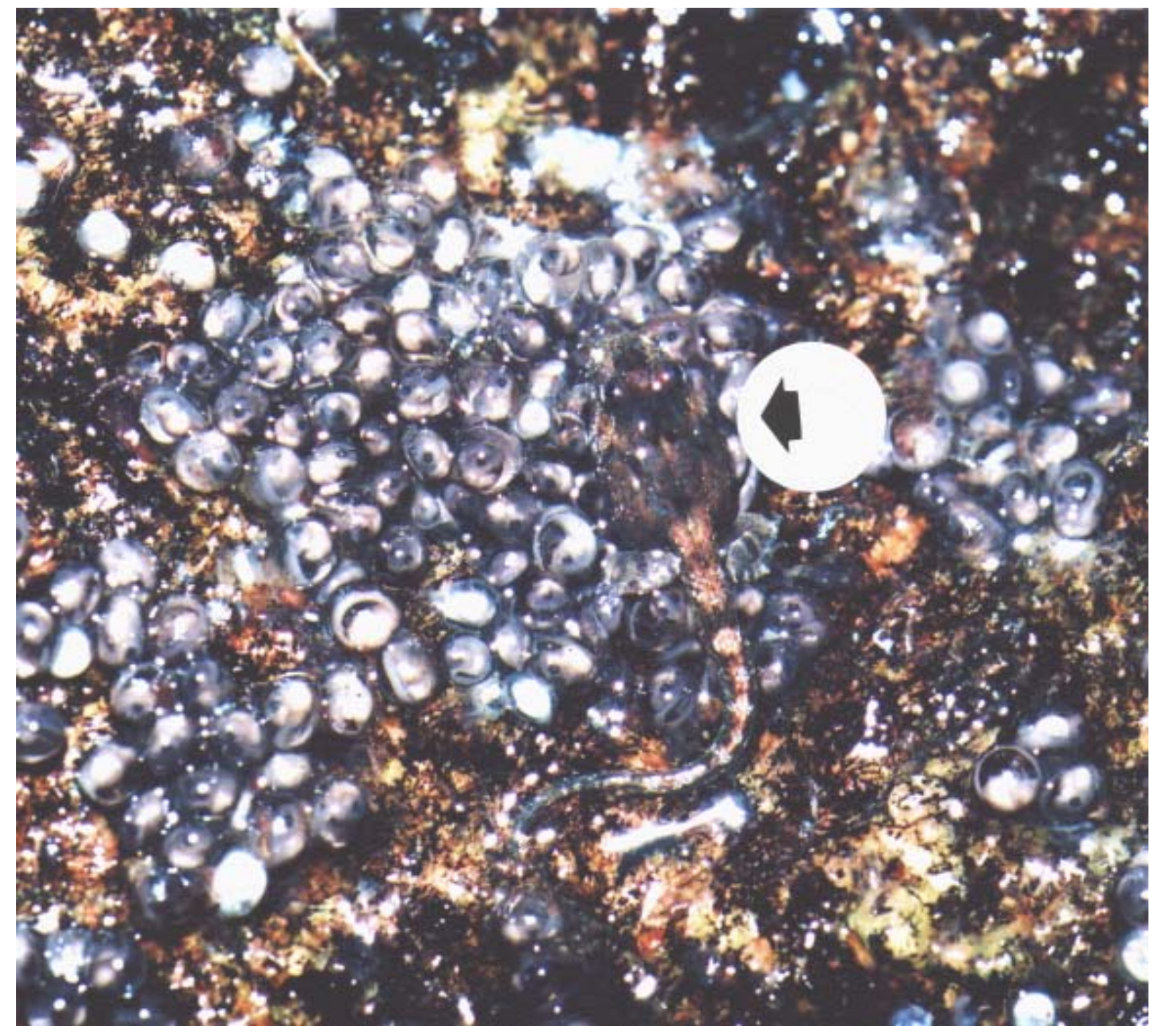

Figure 3- A cannibal tadpole of Thoropa miliaris (arrow) feeding on egg capsules. Municipality of Ubatuba, São Paulo, Brazil. 


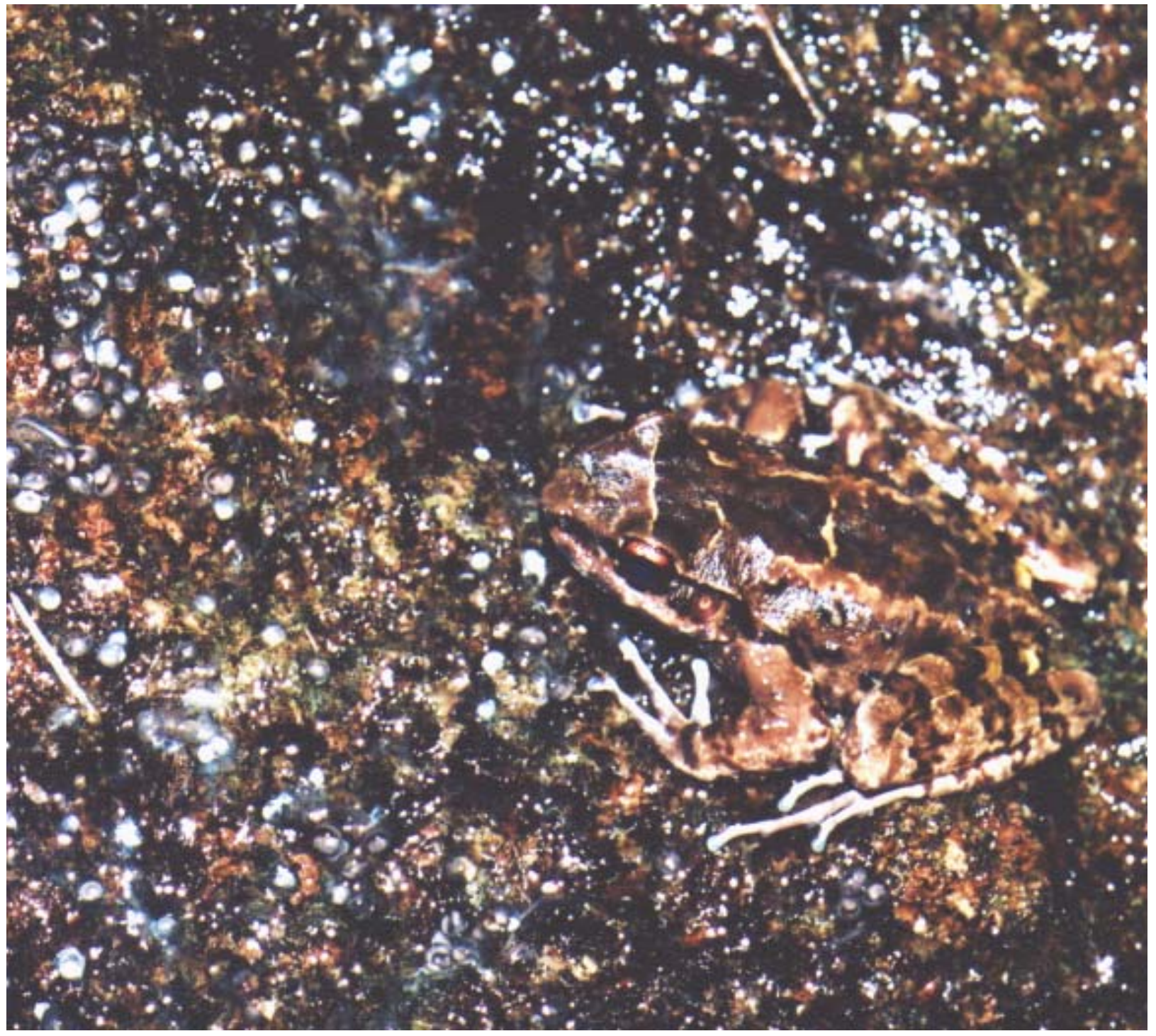

Figure 4- A guarding male of Thoropa miliaris on his egg mass. Municipality of Ubatuba, São Paulo, Brazil. 


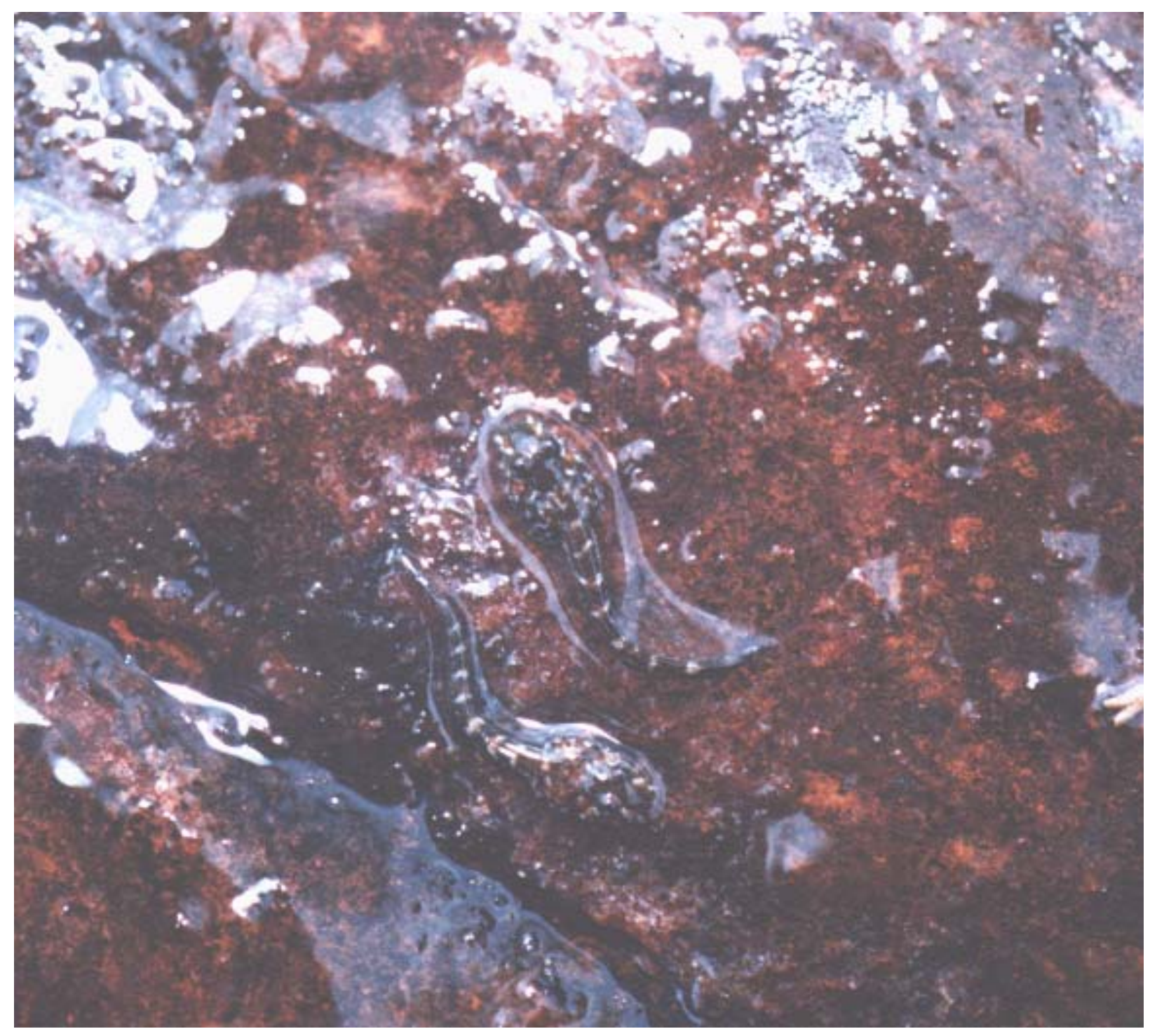

Figure 5. Two tadpoles of Thoropa miliaris in a film of water that flows over a rock surface. Municipality of Ubatuba, São Paulo, Brazil. 
$25 \mathrm{~cm}$ ). There was one egg mass in site 1 and the largest and most agressive male was assumed as being the father. An egg mass laid on site 2 succeeded in hatching, its guardian male was observed on or close $(<10 \mathrm{~cm})$ to the eggs in the second and third nights (62 h) after egg laying. An egg mass was laid on site 3 , and its guarding male remained there five days, even though this egg mass had died from drought three days after being laid.

All males that were guarding egg masses $(n=4)$ reacted by approaching and biting the tip of the stick at least once. The male on site 3 reacted when he was guarding his egg mass, but did not react again two days later when his egg mass had died from drought. In the March period (see below) the large male in site 1 had no egg mass and did not react to the disturbance.

Tadpoles were active in the water film of rock surface (Fig. 5), with a maximum of 20 tadpoles at 22:00 h ( $\mathrm{n}=2$ nights) in the $0.25 \mathrm{~m}^{2}$ plot (site 1$)$; during the day $(\mathrm{n}=2)$ their activities were restricted to shady places. Two large (31 mm total length) and late stage (Gosner 40) tadpoles were found moving on an egg mass during the day (Fig. 3). Close examination revealed that they were feeding on egg capsules of embryos at the stage 23. After the consumption of the capsules, the embryos were exposed and appeared to be dead (motionless) within two minutes ( $\mathrm{n}=4$ tadpoles).

March (2003) - No egg mass was found at this time. On March 5 just the site 1 remained wet and was occupied during the night by a large male (assumed to be the same one of the December/January period). Heavy rains fell during the morning of March 8, and all the three strips became wet again, but, during the following night, only site 1 was occupied by a male. The male of site 1 called that night, but more sporadically when compared to the December/January period. At the $0.25 \mathrm{~m}^{2}$ plot (site 1 ), only two (15 mm TL) tadpoles were found at 21:00 h.

April (2004) - At site 1 we found an apparently unattended egg mass (egg close to hatch) that was adhered to roots and relatively exposed to sunlight. When handling (19:00 h) the eggs, a male appeared from behind the vegetation and approached the egg mass. As the observer (AAG) insisted to touch the eggs with his finger, the male approached even further and reacted by beating the finger with his snout and by grasping fast $(<1$ s) the finger with his arms. During the grasp, the observer felt the finger spines of the male scratching his skin. Besides this observation, it was possible to induce the male to attack (grasp) the observer more two times. The time elapsed from the appearance of the male until the first aggression was about five minutes. No male was heard calling at night in this period.

Egg yolks (ca. $10 \mathrm{~h}$ old) averaged $1.7 \mathrm{~mm}(\mathrm{SD}=0.14, \mathrm{~N}$ $=10$ eggs) in diameter and the eggs averaged $2.3 \mathrm{~mm}$ with the jelly capsule $(\mathrm{SD}=0.24)$. In an older (late cleavage) egg mass, the vitelinic portion averaged $2.1 \mathrm{~mm}(\mathrm{SD}=0.15, \mathrm{~N}=$
$10)$, and the jelly capsules $2.8 \mathrm{~mm}(\mathrm{SD}=0.14, \mathrm{~N}=10)$. The jelly capsules showed at least two layers and were clean, with no sand or debris adhered to them. The yolk of the eggs was uniformly dark gray. Emergence occurred at Gosner stage 23, when the tadpoles were about $10-11 \mathrm{~mm}$ in total length. Newly metamorphosed juveniles averaged $11.1 \mathrm{~mm}$ SVL (SD = 0.60; $N=3)$. Some malformed embryos showed absence of eyes, head or tail and incomplete occlusion of the body wall (yolk remained visible).

One analyzed T. megatympanum female (44 mm SVL, collected on October 1995) had 360 mature ovarian eggs, each averaging $1.7 \mathrm{~mm}$ in diameter $(\mathrm{SD}=0.16 ; \mathrm{n}=10)$. Three T. miliaris females (54.4-67.0 mm SVL, collected between September and December) averaged 705 (SD = 566; range 211 - 1323) mature eggs; eggs averaged 1.9 mm diameter (SD $=0.00 ; \mathrm{n}=20$ eggs; $\mathrm{n}=2$ females). For these two Thoropa species, the eggs were dark gray or dark brown in one hemisphere and light gray in the other. For C. boraceiensis (collected between October and January), mature ovarian eggs averaged 50 ( $\mathrm{SD}=8.9 ; \mathrm{n}=3$ females), yolk averaged $3 \mathrm{~mm}$ in diameter ( $\mathrm{SD}=0.14 ; \mathrm{n}=10 ; \mathrm{n}=1$ female); they were yellow cream with a well-defined smaller darker brown pole.

\section{Discussion}

The male-male aggressive behavior and the fidelity of males to fixed sites of reproduction are indicative of territorial behavior in Thoropa miliaris, as already suggested by Bokermann (1965). The spines on fingers of males of Thoropa species, have been interpreted as serving to agonistic interactions between males (Cocroft \& Heyer, 1988).. Our data on parental care of $T$. miliaris reveled that these spines also can be used against egg predators as well. Among frogs, site fidelity is advantageous if it gives the occupant exclusive or priority access to resources that are in short supply (Wells 1977); female frogs also choose territories in which their offspring have greater chances of surviving (Arak 1983). In the study area, the strips of wet rock represent a limiting factor for reproduction because they are rare and are the only places the eggs and tadpoles can develop. For the males, these wet strips also represent a resource that can be monopolized, making territoriality worthwhile. Besides T. miliaris, territorial behavior is known in other two species of the genus; Heyer \& Crombie (1979) observed fights in T. petropolitana and Cocroft \& Heyer (1988) reported on the presence of figthing scars on the back of $T$. saxatilis.

The greater number of eggs masses and calling males found in December/January period compared to March/April indicates that at Ubatuba T. miliaris reproduces seasonally, with its activity diminishing after January.

Among Thoropa species, egg attendance (sensu Crump 1995) was only reported for T. petropolitana, a species in which the males remain with their eggs and repel 
approaching insects (Heyer \& Crombie 1979). Our observations of attacks of a guarding male of T. miliaris to a human observer turn low probable that in our experiments the reactive guardian males were attracted to the stick by confounding it with food. Heyer \& Crombie (1979) briefly commented that males of $T$. miliaris did not present such egg attendance, in what they were followed by Beck (1998). We interpret this discrepancy as a consequence of a low number of observations or a possible populational variation in the parental care behavior.

Maggots (Diptera larvae) were the only known predators of Thoropa (T. lutzi) eggs (Bokermann 1965) and our report on tadpole cannibalism appears to be the first case among Thoropa species. By being exclusively nocturnal in egg attendance, guardian males of $T$. miliaris apparently cannot provide protection for the eggs against cannibalistic diurnal tadpoles. An intriguing question, that could be tested in future studies, is that the guardian males can be tolerant to tadpole cannibalism, since there is a great chance of the cannibal tadpoles being his own sons. Opportunistic cannibalism appears to be frequent among frogs using phytotelmata (Caldwell \& Araújo, 1998), where unpredictable drying or resource shortage and overcrowding may be common and survivorship may be low (Hoff et al. 1999). These generalizations appear to be applicable to T. miliaris tadpoles. Tadpole cannibalism also may force adult frogs to choose water bodies free or with lower densities of tadpoles for egg laying (Halloy \& Fiano 2000). For T. miliaris females, the use of newly formed wet strips may represent a trade-off between the use of places free of cannibalistic and/or competitive tadpoles and the risks of loss of offspring by drought.

Several studies regarded Thoropa species as presenting small clutch sizes (Bokermann 1965, Heyer \& Crombie 1979, Caramaschi \& Sazima 1984) and having large-sized eggs (Lynch 1971, Lutz 1972). Bokermann (1965) described an egg clutch of T. lutzi Cochran 1938 (28 mm SVL) as having 33 relatively large (yolk $1.7 \mathrm{~mm}$ diameter), and pigmented eggs. Caramaschi \& Sazima (1984) described an egg clutch of T. megatympanum (38 - 48 mm SVL) as having 94 eggs (yolk diameter not stated). We found that female T. miliaris and T. megatympanum bear more than 350 mature ovarian eggs, each one of relatively small size (yolk portion 1.5-1.7 mm diameter). When guarding large egg masses (> 800 eggs), T. miliaris males may be caring for multiple clutches; the scarcity of proper places for egg laying, the variable hatching time within an egg mass, and the extensive area (about $250 \mathrm{~mm}$ diameter) occupied by the egg mass are concordant with this hypothesis.

Thoropa (Telmatobiinae, Batrachylini, cf. Lavilla 1988) and Cycloramphus (Gripiscini, sensu Lynch 1971) species often occur in sympatry in the Atlantic Forest (Heyer et al. 1990) and present similar morphological and reproductive features related to live on wet-rock surfaces (Giaretta \&
Cardoso 1995, Giaretta \& Facure 2003), such as dorso-ventrally flattened adults and semi-terrestrial larvae (Bokermann 1965, Lavilla 1988). The male egg-attendance behavior in Thoropa miliaris described here represents another similar feature of both genera (Lutz 1972, Heyer \& Crombie 1979, Giaretta \& Cardoso 1995, Giaretta \& Facure 2003). In the genus Cycloramphus, some species reached higher levels of specialization toward terrestriality, including endotrophic tadpoles (Heyer \& Crombie 1979).

The taxon Cycloramphinae (Frost 2004) presupposes close phylogenetic relationship between Thoropa and Cycloramphus, however, details of habitat and clutch/egg sizes appear to be quite different in similar sized species of Thoropa and Cycloramphus. Future studies in niche differentiation between forest dweller Thoropa species would reveal that they prefer well-illuminated/hotter sites at the forest border, while Cycloramphus species are strictly umbrophylous. Cycloramphus dubius (Giaretta \& Cardoso 1995) and C. boraceiensis (see also Giaretta \& Facure 2003 and Calphotos) have egg clutches with less than one hundred eggs, each egg being large (3 mm diameter) and cream/ brown colored, while Thoropa species have small and darkpigmented eggs. Considering the morphological dissimilarities (Lynch 1971) and the ecological and behavioral differences between Thoropa and Cycloramphus (present work), we regard as convergence the male parental care in both groups; a firm phylogenetic analysis of leptodactylid frogs would help to make this clear. At present we are reluctant to take the parental behavior of Cycloramphus and Thoropa species as an evidence supporting Cycloramphine (Frost 2004) as a valid taxon.

\section{Acknowledgements}

Dr. W. R. Heyer critically read an early version of the draft. Dr. A. Kwet helped us by providing the wonderful 1907 Wandolleck's paper and by helping us with the German language.

\section{References}

ARAK, A. 1983. Male-male competition and mate choice in anuran amphibians. In Mate Choice (P. Bateson, ed.). Cambridge Univ. Press, Cambridge, p.181 -210.

BECK, C.H. 1998. Mode of fertilization and parental care in anurans. Anim. Behav. 55:439-449.

BOKERMANN, W.C.A. 1965. Notas sobre as espécies de Thoropa Fitzinger (Amphibia, Anura). An. Acad. Bras. Cienc. 37:525-537.

CALDWELL, J.P. \& ARAÚJO, M.C. 1998. Cannibalistic interactions resulting from indiscriminate predatory behavior in tadpoles of poison frogs (Anura: Dendrobatidae). Biotropica 30:92-103. 
CARAMASCHI U. \& SAZIMA, I. 1984. Uma nova espécie de Thoropa da Serra do Cipó, Minas Gerais, Brasil (Amphibia, Leptodactylidae). Rev. bras. Zool. 2:139-146.

COCROFT, R.B. \& HEYER, W.R. 1988. Notes on the frog genus Thoropa (Amphibia: Leptodactylidae) with a description of a new species (Thoropa saxatilis). Proc. Biol. Soc. Wash. 10:209-229.

CRUMP, M.L. 1995. Parental Care. In Amphibian Biology, vol. 2. (H. Heatwole \& B. K. Sullivan, eds.). Surrey Beatty and Sons. Chipping Norton, New South Wales, p. 518 567.

FROST, D.R. 2004. Amphibian Species of the World: an Online Reference. Version 3.0 (22 August, 2004). Electronic Database accessible at http://research.amnh.org/ herpetology/amphibia/index.html. American Museum of Natural History, New York, USA.

GIARETTA, A.A. \& CARDOSO, A.J. 1995. Reproductive behavior of Cycloraphus dubius Miranda-Ribero (Amphibia, Anura, Leptodactylidae). Rev. bras. Zool. 12:233237.

GIARETTA, A.A. \& FACURE, K.G. 2003. Cycloramphus boraceiensis- Egg clutch attendance. Herpetological Review 34:50.

GOSNER K.L. 1960. A simplified table for staging anuran embryos and larvae with notes on identification. Herpetologica 16:183-190.

HALLOY, M. \& FIANO, J.M. 2000. Oviposition site selection in Pleurodema borellii (Anura: Leptodactylidae) may be influenced by tadpole presence. Copeia 2000:606609.

HEYER, W.R. \& CROMBIE, R.I. 1979. Natural history notes on Craspedoglossa stejnegeri and Thoropa petropilitana (Amphibia: Salientia, Leptodactylidae). J. Wash. Acad. Sci. 69:17-20.

HOFF, K., BLAUSTEIN, A.R., MACDIARMID, R. \&ALTIG, R. 1999. Behavior. Interactions and Their Consequences. In Tadpoles. The Biology of Anuran Larvae. (R. MacDiarmid \& R. Altig, eds.). Univ. Chicago Press. Chicago, p. 215-239.

HEYER, W.R., RAND, A.S., CRUZ, C.A.G., PEIXOTO, O.L. \& NELSON, C.E. 1990. Frogs of Boracéia. Arq. Zool. 31:235-410.

LAVILLA, E.O. 1988. Lower Telmatobiinae (Anura: Leptodactylidae): generic diagnoses based on larval characters. Occas. Pap. Mus. Nat. Hist. Univ. Kansas 124:119.

LUTZ, B. 1949. Trends toward non-aquatic and direct development in frogs. Copeia 1949:242-255.

LUTZ, B. 1972. Geographical and ecological notes on Cisandine to Platine frogs. J. Herp. 6:83-100.
LYNCH, J.D. 1971. Evolutionary relationships, osteology, and zoogeography of Leptodactyloid frogs. Univ. Kansas Publ. Mus. Nat. Hist. 53:1-238.

WANDOLLECK, B. 1907. Einige neue und weniger bekannte Batrachier von Brasilien. Abhand. Ber. Königl. Zool. Antrop. Ethno. Mus. Desden 11: 1-16.

WELLS, K.D. 1977. The social behavior of anuran amphibians. Anim. Behav. 25:666-693.

Title: Reproductive Ecology And Behavior Of Thoropa Miliaris (Spix, 1824) (Anura, Leptodactylidae, Telmatobiinae)

Authors: Ariovaldo Antonio Giaretta \& Kátia Gomes Facure

Biota Neotropica, Vol. 4 ( number 2): 2004

http://www.biotaneotropica.org.br/v4n2/pt/ abstract?article+BN03704022004

Date Received 01/05/2003 Revised 02/15/2003

Accepted 03/07/2003

ISSN 1676-0611 